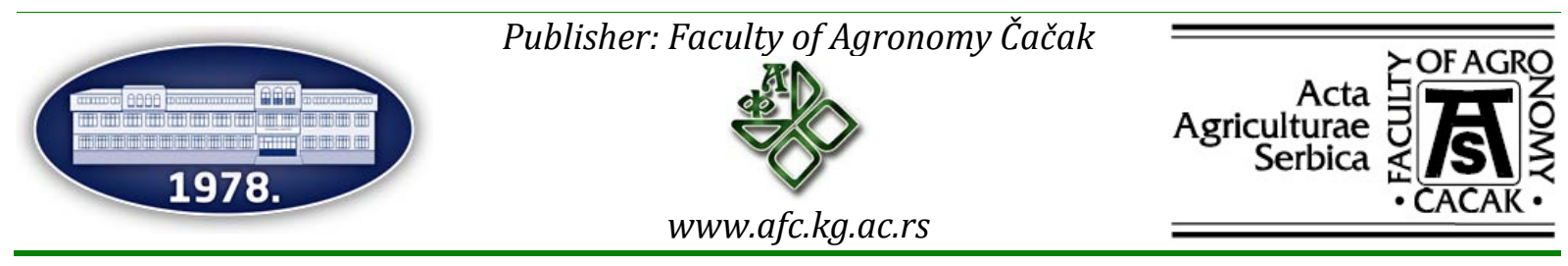

\title{
Impact of rootstock on fruit physical properties of 'Pink Lady' apple
}

\author{
Tomo Milošević $1^{*}$, Nebojša Milošević \\ ${ }^{1}$ Department of Fruit Growing and Viticulture, Faculty of Agronomy, University of Kragujevac, Cara Dušana 34, 32000 \\ Čačak, Serbia \\ ${ }^{2}$ Department of Pomology and Fruit Breeding, Fruit Research Institute Čačak, Kralja Petra I 9, 32000 Čačak, Serbia \\ *Corresponding author: tomomilosevic@kg.ac.rs
}

Received 8 February 2021; Accepted 28 April 2021

\begin{abstract}
A B S T R A C T
During 2018 and 2019, we evaluated the main fruit physical properties [weight (FW), length (L), diameter (D), geometric mean diameter $\left(D_{g}\right)$, length/diameter ratio (L/D ratio), sphericity $(\varphi)$, surface area (S), fruit volume (V) and solid density $\left.(\rho)\right]$ of 'Pink Lady' apple grafted on dwarf M.9 T337, semi-dwarf M.26 and semi-vigour MM.106 rootstocks. Results showed that rootstocks significantly changed the properties evaluated with the exception of L/D ratio, $\varphi$ and $\rho$. Among rootstocks, M.9T33 7 produced the best properties, whereas lower and statistically similar values were obtained from M.26 and MM.106 rootstocks. All rootstocks promoted D higher than $66 \mathrm{~mm}$, whereas only M.9 T337 induced D $\geq 70 \mathrm{~mm}$. The rootstocks did not have the capacity to change the fruit shape of the 'Pink Lady' club cultivar.
\end{abstract}

Keywords: club cultivar, fruit size, fruit weight, fruit shape indexes, Malus domestica Borkh., rootstock.

\section{И 3 В $О$ Д}

Током 2018. и 2019. године оцењивали смо главна физичка својства плода [маса (FW), дужина (L), пречник (D), средњи геометријски пречник ( $\left.\mathrm{D}_{\mathrm{g}}\right)$, однос дужина/пречник (L/D однос), сферичнофт), (Iовршина (S), запремина (V) и специфична маса (९)] сорте 'Pink Lady' калемљене на кржљавој M.9 T337, полукржљавој M.26 и средњебујној ММ.106 подлози. Резултати су показали да су подлоге значајно мењале испитиване особине са изузетком L/D односа, $\varphi$ и $\rho$. Међу подлогама, M.9 Т337 је условила најбоље вредности, док су мање и статистички сличне вредности промовисале подлоге M.26 и ММ.106. Све подлоге су изазвале пречник плода већи од 66 mm, док је само М.9 Т337 индуковала пречник плода $\geq 70 \mathrm{~mm}$. Подлоге нису имале способност да промене облик плода клуб сорте 'Pink Lady'.

Кључне речи: клуб сорта, крупноћа плода, тежина плода, индекси облика плода, Malus domestica Borkh., подлога.

\section{Introduction}

Grafting is the most common way of propagating fruit trees and dates back several thousand years or more. This method of vegetative propagation is used for two principal reasons: many fruit trees do not come true from seed since woody species are highly heterozygous (seeds from a 'Golden Delicious' apple will not grow into 'Golden Delicious' trees) and cuttings do not root easily. Grafting can be defined as a natural or deliberate fusion of plant parts by which vascular continuity is established between them (Pina and Errea, 2005) and the resulting genetically composite organism functions as a single plant.

As known, rootstocks are of paramount importance in modern fruit production due to their capability of adapting scion cultivars to diverse environmental conditions and cultural practices. In recent decades, many studies have addressed the influence of rootstocks on scion properties and vice versa. It has been irrefutably proven that this part of the plant has a multiple effect on the grafted scion i.e. cultivar. Namely, rootstock plays a major role in growth pattern, tree vigour, tolerance to biotic and abiotic stresses (drought, winter hardiness, pathogens, diseases, potentially toxic compounds in the soil such as salt or heavy metals), photosynthetic rate, leaf nutrient composition, adaptability to climate and soil conditions, bearing age, productivity and fruit quality (Lochard and Schneider, 1981; Kappel et al., 1997; AlHinai and Roper, 2004; Sotiropoulos, 2006; Kheiralipour et al., 2008; Ikinci and Bolat, 2019; Milošević et al., 2018, 2019). A harmonious combination of rootstock and cultivar is a desirable category in fruit growing due to the interaction between them as well as with soil and climatic conditions of the prevailing area (Kosina, 2009).

Successful fruit production requires hardy, disease-resistant cultivars with high fruit quality, mainly a long-term consumption period (Khanizadeh et al., 2000). Modern apple production is based on growing cultivars with adequate consumer acceptability that are grafted on dwarfing rootstocks, and with $3,000-5,000$ trees per hectare in orchards. The predominant rootstock worldwide in highly intensive orchards is M.9 with clones, especially M.9 T337, followed by semi-dwarf MM.106 for spur types of apples such as 'Starking', 'Starkrimson' and 'Red Chief Delicious'. In Serbian apple orchards, MM.106 is often used, especially for the 'Idared' cultivar, since the trees 
have moderate tree size suitable for semi-dense planting systems. M.26 rootstock (with tree vigour between M.9 and MM.106) is rarely used in European orchards; however, recently, in Serbian irrigated plantations, 'Idared' has often been grafted on this rootstock.

There are hundreds of apple cultivars. Dobrzañski et al. (2006) mention more than 7,500 known apples, but only between 20 and 40 are produced and commercially traded around the world (Somogyi et al., 1996; Strohm, 2013). Among them, only 13 covered nearly $72 \%$ of the entire European apple acreage in 2007. 'Golden Delicious' with clones (16.3\%) had the highest share, followed by 'Jonagold' ( $9.7 \%)$ and 'Gala' (8.6\%) mainly in Italy, Spain, France, Germany and Poland (Strohm, 2013). Relatively new cultivars such as 'Pink Lady', a club cultivar bred in the 1970s, are becoming more popular in Europe. The cultivar was selected from a breeding programme at Stoneville Horticultural Research Station near Perth in Western Australia, and imported into New Zealand, where it has been grown on a commercial scale for export (Corrigan et al., 1997). 'Pink Lady' originated from a cross between 'Lady Williams' and 'Golden Delicious' in 1973 by J.E.L. Cripps (Cripps et al., 1993). According to the consumer panel assessment of five late-harvest apples, 'Pink Lady' had the best ratings for consumer acceptability, purchase frequency, purchase price and "nicest" looking apple in comparison with 'Braeburn', 'Fuji', 'Granny Smith' and 'Red Dougherty' (Corrigan et al., 1997).

However, the cultivation of 'Pink Lady' as a club cultivar is limited and strictly controlled. If a potential grower obtains approval from the owner of this cultivar for the cultivation and sale of fruit, a high royalty fee is paid. For these and other reasons, Serbian growers and consumers are not familiar with 'Pink Lady' apple. Therefore, we decided to examine the most important physical characteristics of the fruit of this cultivar grafted on three clonal rootstocks differing in vigour in order to gain better knowledge of its external fruit quality and reaction to these rootstocks.

\section{Materials and methods}

\subsection{Plant material and experimental setup}

Apple $c v$. 'Pink Lady' (Fig. 1), also called 'Cripps Pink', grafted on dwarf M.9 T337 rootstock, semi-dwarf M.26 rootstock and medium-vigour MM.106 rootstock was used as a plant material. The orchard was

Table 1.

Equations for calculating some physical parameters of the fruit and their creators

\begin{tabular}{lcr}
\hline Equation & Source & Serial number \\
\hline$D_{g}=\sqrt[3]{L W^{2}}$ & Mohsenin (1986) \\
$\varphi=\sqrt[D_{g}]{L}$ & Mohsenin (1986) \\
$S=\pi D_{g}^{2}$ & McCabe et al. (1986) \\
$V=\frac{4}{3} \pi\left(\frac{L}{2}\right)\left(\frac{D^{2}}{2}\right)$ & Torabi et al. (2013) \\
$\rho=F W / V$ & Mohsenin (1986)
\end{tabular}

established in 2006 , at a $3.0 \mathrm{~m} \times 1.2 \mathrm{~m}$ planting distance; the training system was slender spindle.

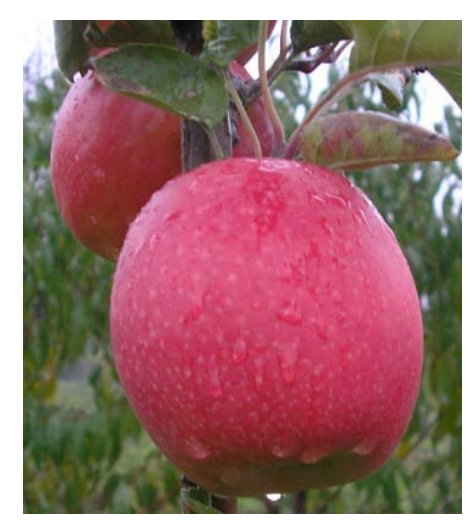

Figure 1. Fruits of 'Pink Lady' (Source: T. Milošević, original)

The orchard was located in Prislonica village $\left(43^{\circ} 57^{\prime} \mathrm{N}, 20^{\circ} 26^{\prime} \mathrm{E}\right)$ near the city of Čačak, western Serbia at $320 \mathrm{~m}$ a.s.l. and managed following the usual standard procedures under a non-irrigated practice. Fruit thinning was not performed in order to maintain rootstock/cultivar combination was represented by 5 trees in three replications in a randomised block design.

Soil and weather conditions for this area were explained in our earlier study on apple (Milošević et al., 2019).

\subsection{Measurements of fruit physical properties}

Fruits were randomly hand picked (15 fruits in three replicates, $n=45$ ) at the end of the second tenday period of November in 2018 and 2019 from all parts of the canopy. Then, fruits were transported to the laboratory of the Faculty of Agronomy in Čačak and their physical properties were determined. Fruit weight (FW) was measured on a MAULsteel $5000 \mathrm{G}$ digital balance (Jakob Maul GmbH, Bad König, Germany). Fruit linear dimensions - length (L) and diameter (D) (both in $\mathrm{mm}$ ) - were measured using a Starrett 727 caliper gauge (Athol, MA, USA). L/D ratio, also called fruit elongation index, was calculated.

Other physical properties such as geometric mean diameter $\left(D_{g}, m m\right)$, sphericity $(\varphi)$, surface area $\left(S, \mathrm{~cm}^{2}\right)$, volume $\left(\mathrm{V}, \mathrm{cm}^{3}\right)$ and apparent solid density $\left(\rho, \mathrm{kg} \mathrm{m}^{-3}\right)$ were calculated by using the equations presented in Table 1. the apparent impact of the rootstock evaluated. Each 


\subsection{Data analysis}

Data for both 2018 and 2019 were pooled and then they were calculated as mean values. The results were processed statistically by analysis of variance (ANOVA) using the Microsoft Office Excel software (Microsoft Corporation, Redmond, WA, USA). The significance of differences between means was determined by LSD test at $P \leq 0.05$.

\section{Results and discussion}

Fruit weight differed significantly between M.9 T337 and the other two rootstocks (Table 2). The heaviest fruits were harvested from M.9 T337 whereas
M.26 and MM.106 produced the lightest on average, with no significant differences between them. This information is useful for fruit classification by weight and size as well as for optimal packaging calculations and design (Tabatabaeefar and Rajabipour, 2005; Kheiralipour et al., 2008). Fruit length was the highest in 'Pink Lady' on M.9 T337, intermediate on M.26 and the lowest on MM.106. Fruit diameter, as an important parameter for fruit grading and packaging, was higher on M.9 compared to both M.26 and MM.106 rootstocks, which had statistically similar values. Similar tendencies were observed for $\mathrm{D}_{\mathrm{g}}$, also called fruit size index (Table 2). As known, fruit size is an important factor determining consumer acceptability, productivity and price (Al-Hinai and Roper, 2004).

Table 2.

Weight, fruit linear dimensions (length and diameter), size and shape indexes of 'Pink Lady' fruits on three clonal rootstocks

\begin{tabular}{ccccc}
\hline Rootstock & $\begin{array}{c}\text { Fruit weight } \\
(\mathrm{g})\end{array}$ & $\begin{array}{c}\text { Fruit length } \\
(\mathrm{mm})\end{array}$ & $\begin{array}{c}\text { Fruit diameter } \\
(\mathrm{mm})\end{array}$ & $\begin{array}{c}\text { Geometric mean } \\
\text { diameter } \\
(\mathrm{mm})\end{array}$ \\
\hline M.9 & $159.55 \pm 6.00 \mathrm{a}$ & $64.70 \pm 1.22 \mathrm{a}$ & $70.22 \pm 0.95 \mathrm{a}$ & $68.31 \pm 1.01 \mathrm{a}$ \\
M.26 & $138.95 \pm 5.97 \mathrm{~b}$ & $61.29 \pm 1.18 \mathrm{~b}$ & $66.15 \pm 0.99 \mathrm{~b}$ & $64.47 \pm 1.02 \mathrm{~b}$ \\
MM.106 & $134.35 \pm 3.94 \mathrm{~b}$ & $60.14 \pm 0.74 \mathrm{c}$ & $66.01 \pm 0.67 \mathrm{~b}$ & $64.03 \pm 0.62 \mathrm{~b}$ \\
\hline
\end{tabular}

The different small letter(s) in columns indicate significant differences among means for each rootstock at $P \leq 0.05$ by LSD test

The potential for fruit size development in apple is determined by crop load and the genetic carrying capacity of each cultivar, as well as by environmental conditions and cultural practices such as rootstock, thinning, fertilization and irrigation. Jones et al. (1997) reported fruit weight of 'Pink Lady' between 124.2 and $187.7 \mathrm{~g}$ in southern Tasmania and Henríquez et al. (2010) $273.05 \mathrm{~g}$ in Chile. In a study by Talluto et al. (2008) performed in Sicily, the FW of 'Pink Lady' was $146 \mathrm{~g}$ under non-irrigated conditions and $196 \mathrm{~g}$ under irrigation. These authors also reported that M.9 increased fruit weight whereas MM.106 decreased it. Similar tendencies were found by Marini et al. (2002), who reported that M.9 showed the best effect on the FW of 'Gala' compared to 7 dwarfing rootstocks. We also found a positive effect of M.9 on this trait in our earlier study on apple (Milošević et al., 2019). According to Cripps et al. (1993), 'Pink Lady' fruits are medium to large in size $(70$ to $75 \mathrm{~mm}$ average diameter). In our study, all rootstocks induced a diameter greater than $66 \mathrm{~mm}$, which is the first class of apple fruits in trade; however, only M.9 T337 produced fruits with a diameter $\geq 70 \mathrm{~mm}$. Cripps et al. (1993) also suggested that dwarfing rootstock should be used for 'Pink Lady'; MM.106 is generally suitable, MM.104 and MM.109 rootstocks have also been used in evaluations, but M.26, which could be suitable, has not been tested. Our data for FW and both fruit linear dimensions were much lower than those obtained by Henríquez et al. (2010) and Özongun et al. (2014) for the same cultivar grafted on MM.106.

Sphericity is an expression of the shape of a solid relative to that of a sphere of the same volume which is indicative of its tendency toward being generally oblong in shape (Omobuwajo et al., 1999). Despite lower values of M.26 and MM.106 for L and D, all rootstocks produced fruit of a statistically similar shape (Table 3). According to Cripps et al. (1993), 'Pink Lady' is oblong-conical in shape, which confirmed our L/D ratio and $\varphi$ values.

Table 3.

Fruit physical properties of 'Pink Lady' grafted on three clonal rootstocks

\begin{tabular}{cccccc}
\hline Rootstock & $\begin{array}{c}\text { L/D ratio } \\
\text { (Elongation) }\end{array}$ & Sphericity & $\begin{array}{c}\text { Surface area } \\
\left(\mathrm{cm}^{2}\right)\end{array}$ & $\begin{array}{c}\text { Fruit volume } \\
\left(\mathrm{cm}^{3}\right)\end{array}$ & $\begin{array}{c}\text { Solid density } \\
\left(\mathrm{kg} \mathrm{m}^{-3}\right)\end{array}$ \\
\hline M.9 & $0.92 \pm 0.01 \mathrm{a}$ & $1.06 \pm 0.01 \mathrm{a}$ & $147.14 \pm 4.40 \mathrm{a}$ & $168.93 \pm 7.67 \mathrm{a}$ & $971.80 \pm 46.40 \mathrm{a}$ \\
M.26 & $0.93 \pm 0.01 \mathrm{a}$ & $1.05 \pm 0.01 \mathrm{a}$ & $131.15 \pm 4.20 \mathrm{~b}$ & $142.29 \pm 6.92 \mathrm{~b}$ & $1016.25 \pm 61.06 \mathrm{a}$ \\
MM.106 & $0.91 \pm 0.01 \mathrm{a}$ & $1.07 \pm 0.01 \mathrm{a}$ & $128.98 \pm 2.52 \mathrm{~b}$ & $138.14 \pm 4.09 \mathrm{~b}$ & $994.23 \pm 47.81 \mathrm{a}$ \\
\hline
\end{tabular}

The different small letter(s) in columns indicate significant differences among means for each rootstock at $P \leq 0.05$ by LSD test

Relatively high L/D ratio and $\varphi$ values of 'Pink Lady' apple on all rootstocks are indicative of the tendency towards a sphere. These values also indicated that Pink Lady' fruit might follow the combination of rolling and sliding action on its flat surfaces. The values of the $L / D$ ratio (which relates the fruit $L$ to $D$ ) in our study may suggest that 'Pink Lady' will roll rather than slide on its oblong-conical surfaces. However, the values of the $\mathrm{L} / \mathrm{D}$ ratio found to be close to the $\varphi$ values may also mean that the fruit of this cultivar will undergo a combination of rolling and sliding action on its flat surfaces (Khan et al., 2019). 
Surface area is important when expressing the transfer of heat, water vapour, gases, pesticides, and foliar nutrients into or out of fruits (Clayton et al., 1995) and would be useful in determining the mass of the cuticular membrane per unit fruit surface area (Peschel et al., 2007). Fruit volumes must be known for accurate modelling of heat and mass transfer during cooling and drying (Wright et al., 1986). As expected, S and V were higher on M.9 T337 than on both M.26 and MM.106 rootstocks, with no significant differences between them (Table 3). Results obtained by Ikinci and Bolat (2019) showed that the clonal rootstocks M.9 and MM.106 induced better fruit size and volume of 'Anna' apple than seedling rootstock.

Solid density $(\rho)$ is the weight per unit volume of the solid material and excludes any interior pores which are filled with air. This trait is important for the drying process in order to achieve desirable properties without an unnecessary expenditure of energy. Statistically, there were no significant differences in solid density for the studied rootstocks (Table 3). Significant differences in this trait have also not been found in other studies (Ortega et al., 2013). Mišić (2004) reported that solid density in apple fruits varied from $0.78 \mathrm{~g} \mathrm{~cm}^{-2}$ in 'Jonathan' to $0.91 \mathrm{~g} \mathrm{~cm}^{-2}$ in 'London Pippin' (syn.: 'London Pepping'), whereas O'Neill et al. (1998) and Kheiralipour et al. (2008) reported a solid density of $837 \mathrm{~kg} \mathrm{~m}^{-3}$ in 'Gala' apple and 837.68 to $827.91 \mathrm{~kg} \mathrm{~m}^{-3}$ in 'Red Spur' and 'Delbard Estivale' apples, respectively. In a study by Ozturk et al. (2010), solid density was $887.82 \mathrm{~kg} \mathrm{~m}^{-3}$ for 'Granny Smith', $948.56 \mathrm{~kg} \mathrm{~m}^{-3}$ for 'Golden Delicious' and $950.87 \mathrm{~kg} \mathrm{~m}^{-3}$ for 'Starking Delicious'. Our data for this trait were higher than those obtained by the above-mentioned authors probably due to genetic factors and fruit ripening stage. Torabi et al. (2013) reported a strong cultivar effect on solid density in apple. Interestingly, although differences among the rootstocks were not significant, the fruits of 'Pink Lady' on M.26 were heavier than the density of water, while the others were close to 1 (if the $\rho$ values are expressed in $\mathrm{g} \mathrm{cm}^{-3}$ ), indicating that the fruits were prematurely harvested and unsuitable for the processing industry, especially drying. This statement primarily refers to the fruits of 'Pink Lady' that do not meet the criteria for fresh consumption.

\section{Conclusions}

The choice of a suitable rootstock is paramount for obtaining the desired physical properties of apple fruit. The obtained results showed that fruit weight, dimensions, size, surface area and fruit volume were significantly influenced by the choice of rootstock. However, the influence of rootstocks on fruit shape indices and solid density was not significant. The best traits evaluated were achieved when 'Pink Lady' was grafted on dwarfing rootstock i.e. M.9 T337, which indicates its superior positive effect on fruit physical properties. There is no doubt that the impact of rootstock on fruit quality attributes is much more complicated than some variables can measure. Information on engineering properties of $c v$. 'Pink Lady' may be useful in designing much of the equipment used for handling, grading, sizing and packing systems, conveying and postharvest processing; however, further work is required to substantiate the results obtained in this study.

\section{Funding}

The authors received no funding for this work.

\section{Competing Interests}

The authors declare there are no competing interests.

\section{Author Contributions}

Tomo Milošević conceived and designed the experiment, prepared figures and tables, authored or reviewed drafts of the paper, and approved the final draft. Nebojša Milošević performed the experiments, analyzed the data, and approved the final draft.

\section{References}

Al-Hinai, Y.K., Roper, T.R. (2004). Rootstock effects on growth and quality of 'Gala' apples. HortScience, 39(6), 12311233. doi: 10.21273/HORTSCI.39.6.1231

Clayton, M., Amos, N.D., Banks, N.H, Morton, R.H. (1995). Estimation of apple fruit surface area. New Zealand Journal of Crop and Horticultural Science, 23(3), 345-349. doi: 10.1080/01140671.1995.9513908

Corrigan, V.K., Hurst, P.L., Boulton, G. (1997). Sensory characteristics and consumer acceptability of 'Pink Lady' and other late-season apple cultivars. New Zealand Journal of Crop and Horticultural Science, 25(4), 375-383. doi: 10.1080/01140671.1997.9514029

Cripps, J.E.L., Richards, L.A., Mairata, A.M. (1993). 'Pink Lady' apple. HortScience, 28(10), 1057-1057. doi: 10.21273/HORTSCI.28.10.1057

Dobrzañski, B., Rabcewicz, J., Rybczyñski, R. (2006). Handling of apple. IA PAS Press, Lublin, Poland.

Henríquez, C., Almonacid, S., Chiffelle, I., Valenzuela, T., Araya, M., Cabezas, L., Simpson, R., Speisky, H. (2010). Determination of antioxidant capacity, total phenolic content and mineral composition of different fruit tissue of five apple cultivars grown in Chile. Chilean Journal of Agricultural Research, 70(4), 523-536.

Ikinci, A., Bolat, I. (2019). The effect of some rootstocks on the physical and chemical properties of fruit growing process in Anna apple cultivar. Fresenius Environmental Bulletin, 28(4), 2855-2863.

Jones, K.M., Bound, S.A., Summers, C.R., Oakford, M.J. (1997). Preliminary examination of thinning strategies on young 'Jonagold' and 'Pink Lady' apples. Australian Journal of Experimental Agriculture, 37(3), 377-382. doi: 10.1071/EA96088

Keppel, H., Youssef, J., Toffolutti, B., Mantiger, H., Stainer, R., Zadravec, P. (1997). Performance of Smoothee apple cultivar on various rootstocks. L'Informatore Agrario, 53, 17-127.

Khan, M.A., Singh, K., Patel, K.K., Siddiqui, M. (2019). Some physical properties of wood apple (Feronia limonia L.). Recent Advancement in Food Science and Nutrition Research, 2(1), 79-86. doi: 10.29199/2638-9770/FSNR201022

Khanizadeh, S., Grzyb, Y., Cousineau, J., Granger, R., Rousselle, G. (2000). New hardy apple selections from the Quebec apple breeding program. Acta Horticulturae, 538, 715718. doi: 10.17660/ActaHortic.2000.538.129

Kheiralipour, K., Tabatabaeefar, A. Mobli, H., Rafiee, S., Sahraroo, A., Rajabipour, A., Jafari, A. (2008). Some physical properties of apple. Pakistan Journal of Nutrition, 7(5), 667-672. doi: 10.3923/pjn.2008.667.672

Kosina, J. (2009). Performance of 'Gloster' and 'Melrose' apple trees on Czech rootstocks and M.9 clones. Acta Horticulturae, 814, 425-428. doi: 10.17660/ActaHortic.2009.814.71

Lochard R.G., Schneider G.W. (1981). Stock and scion relationships and the dwarfing mechanism in apple. Horticultural Reviews, 3, 315-375. 
Marini, R.P., Barden, J.A., Cline, J.A., Perry, R.L., Robinson, T. (2002). Effect of apple rootstocks on average 'Gala' fruit weight at four locations after adjusting for crop load. Journal of the American Society for Horticultural Science, 127(5), 749-753. doi: 10.21273/JASHS.127.5.749

McCabe, W.L., Smith, J.C., Harriott, P. (1986). Unit operations of chemical engineering. McGraw-Hill, New York.

Milošević, T., Milošević, N., Mladenović, J. (2018). Role of apple clonal rootstocks on yield, fruit size, nutritional value and antioxidant activity of 'Red Chief ${ }^{\circledR}$ Camspur cultivar. Scientia Horticulturae, 236(10), 214-221. doi: 10.1016/j.scienta.2018.03.050

Milošević, T., Milošević, N., Mladenović, J. (2019). Role of rootstock and apple fruit tissue in antioxidant activity. Acta Agriculturae Serbica, 24(48), 97-106. doi: 10.5937/AASer1948097M

Mišić, P.D.( 2004). Apple. Nolit, Belgrade, 328 p. (in Serbian)

Mohsenin, N.N. (1986). Physical properties of plant and animal materials. Gordon and Breach, New York.

O'Neill, M.B., M. Rahman, M.S., Perera, C.O., Smith, B., Melton, L.D. (1998). Color and density of apple cubes dried in air and modified atmosphere. International Journal of Food Properties, 1(3), 197-205. doi: 10.1080/10942919809524577

Omobuwajo, T.O., Akande, A.E., Sanni, L.A. (1999). Selected physical, mechanical and aerodynamic properties of African breadfruit (Treculia africana) seeds. Journal of Food Engineering, 40(4), 241-244. doi: 10.1016/S02608774(99)00060-6

Özongun, Ş., Dolunay, E.M., Öztürk, G., Pektaș, M. (2014). Performance of some apple varieties in Eğirdir (Isparta) conditions. Fruit Science, 1(2), 21-29. (in Turkish)

Ozturk, I., Bastaban, S., Ercisli, S., Kalkan, F. (2010). Physical and chemical properties of three late ripening apple cultivars. International Agrophysics, 24(4), 357-361.
Peschel, S., Franke, R., Schreiber, L., Knoche, M. (2007). Composition of cuticle of developing sweet cherry fruit. Phytochemistry, 68(7), 1017-1025. doi: 10.1016/j.phytochem.2007.01.008

Pina, P., Errea, P. (2005). A review of new advances in mechanism of graft compatibility-incompatibility. Scientia Horticulturae, 106(1), 1-11. doi: 10.1016/j.scienta.2005.04.003

Somogyi, L.P., Barrett, D.M., Hui, Y.H. (1996). Processing fruits: Science and technology. Major processed products. Vol. 2, Technomics Publishing Company Inc., Lancaster, PA, USA.

Sotiropoulos, T. (2006). Performance of the apple cultivar 'Golden Delicious' grafted on five rootstocks in Northern Greece. Archives of Agronomy and Soil Science, 52(3), 347-352. doi: 10.1080/03650340600612532

Strohm, K. (2013). Apple production in Germany. Agri benchmark Horticulture Conference, September 23-28, 2013, Germany. Available at: http://www.agribenchmark.org

Tabatabaeefar, A., Rajabipour, A. (2005). Modeling the mass of apples by geometrical attributes. Scientia Horticulturae, 105(3), 373-382. doi: 10.1016/j.scienta.2005.01.030

Talluto, G., Farina, V., Lo Bianco, R. (2008). Effects of partial rootzone drying and rootstock vigour on growth and fruit quality of 'Pink Lady' apple trees in Mediterranean environments. Australian Journal of Agricultural Research, 59(9), 785-794. doi: 10.1071/AR07458

Torabi, A., Tabatabaekoloor, R., Hashemi, S.J. (2013). Volume modeling of three apple varieties based on physical parameters. International Journal of Agriculture and Food Science Technology, 4(5), 461-466.

Wright, M.E., Toppan J.H., Sistler F.E. (1986). The size and shape of typical sweet potatoes. Transactions of the ASAE, 29(3), 678-682. doi: 10.13031/2013.30212 
